\title{
Primary Pulmonary Malignant Melanoma: A Case Report and Literature Review
}

\author{
Sama Byanju, Jie Chen, DongYong Zhu and MeiYan Liao \\ Department of Radiology, Zhongnan Hospital of Wuhan University, No.169 East lake Road, Wuchang District, Wuhan City, Hubei province, PR China
}

"Corresponding author: MeiYan Liao, Department of Radiology, Zhongnan Hospital of Wuhan University, No.169 East lake Road, Wuchang District, Wuhan City, Hubei province, PR China, Tel: +862767812999; E-mail: liaomy@whu.edu.cn

Received Date: Mar 26, 2018; Accepted Date: Apr 13, 2018; Published Date: Apr 24, 2018

Copyright: @ 2018 Byanju S, et al. This is an open-access article distributed under the terms of the Creative Commons Attribution License, which permits unrestricted use, distribution, and reproduction in any medium, provided the original author and source are credited.

\begin{abstract}
Background: Primary pulmonary malignant melanoma (PMM) is an extremely rare disease entity. There are limited published data on primary pulmonary malignant melanomas. The clinical manifestations and imaging features are non-specific. The imaging features of pulmonary melanoma have been described in previous reports, but it is still challenging to diagnosis it radiologically.
\end{abstract}

Case presentation: A 66 years old male presented with productive cough and back pain. His chest computed tomography (CT) scan revealed homogenous mass with higher density in left hilum with metastatic nodules in lungs. The metastatic lesions in vertebra on magnetic resonance imaging (MRI) were hyper-intense on T1WI and hypointense on T2WI. Further evaluation and immunohistochemical examination confirmed the diagnosis of primary pulmonary malignant melanoma with metastasis to vertebral bodies, liver, adrenal and lungs. He received 2 cycles of chemotherapy and died one month after initial diagnosis of the disease.

Conclusion: We have described pulmonary melanoma as bilateral homogenous nodules and mass with a higher computed tomography value. Although CT value has not been described in all literatures, many cases displayed higher density masses. So, clinicians should consider primary lung melanoma as a differential diagnosis for patients with such higher density mass in CT scan and hyper-intensity on T1WI and hypo-intensity on T2WI on MRI.

Keywords: Primary malignant melanoma; Lung; imaging manifestations

\section{Introduction}

Melanoma, a malignant neoplasm of melanocytes, is one of the most aggressive cancers. Although malignant melanoma mainly occurs on the skin, it occurs in other mucosal sites and organs, including the oral cavity, paranasal sinuses, larynx, esophagus, liver, vagina, and anorectal region [1]. Worldwide, approximately 160,000 new cases of melanoma are diagnosed each year. Approximately $5-10 \%$ of patients with metastatic melanoma have a primary melanoma of unknown origin [1-3]. Commonly malignant melanoma of the respiratory system is metastatic in origin. Primary malignant melanoma of the lung is an extremely rare non-epithelial neoplasm with poor prognosis that accounts for only $0.01 \%$ of all primary lung tumors and only few cases have been reported [2,4]. Extra-pulmonary origin of the tumor including occult primary tumors must be excluded by the proposed clinical and pathological criteria before considering this diagnosis $[3,5]$.

\section{Case Report}

A 66-years-old man with medical history of hypertension for 8 years and stroke for 2 years and smoking history of 100 pack years since 13-63 years of age presented with complaints of productive cough and back pain for 1 month. The patient was suspected to have chest infection and empirically given antibiotic therapy in other hospital. The patient did not improve, and then he was referred to our hospital for further investigation and treatment.

His initial laboratory values were within the reference ranges. His chest X-ray showed bilateral nodules and mass lesions. The chest computed tomography without contrast (Figures 1a-1c) revealed bilateral multiple nodules and masses (mean CT value of $67 \mathrm{HU}$ ) and bilateral minimal pleural effusion. A large irregular heterogeneous mass measuring $6.9 \times 6.5 \mathrm{~cm}$ was seen in the left hilum causing narrowing of the left lower bronchus. The other irregular solid mass measuring $4.3 \times 3.6 \mathrm{~cm}$ was seen in the right lower lung lobe. Multiple nodules were noted around the pericardium. In the bone window, osteolytic destruction were seen on right fifth back ribs and multiple thoracic vertebral. The upper abdominal CT displayed multiple nodules in liver, spleen and bilateral adrenals (Figure 1d) (mean CT value of $52 \mathrm{HU}$ ) and multiple enlarged mesenteric and retroperitoneal lymph nodes (mean CT value of nodules is $57 \mathrm{HU}$ ).

The subsequent metastatic workup of brain and spinal nonenhanced magnetic resonance imaging (MRI) (Figure 2) showed multiple nodules in parietal bone (Figure 2c) and vertebral bodies (Figure 2a-2d) and multiple cervical lymphadenopathy. The lesions were hypo-intense on T1WI and hyper-intense on T2WI. The whole body bone scintigraphy showed increased metabolic activity of left clavicle, bilateral scapula, multiple ribs, 10th thoracic vertebrae and right ischial bone. 
Citation: Byanju S, Chen J, Zhu DY, Liao MY (2018) Primary Pulmonary Malignant Melanoma: A Case Report and Literature Review. Med Rep Case Stud 3: 155. doi:10.4172/2572-5130.1000155

Page 2 of 8

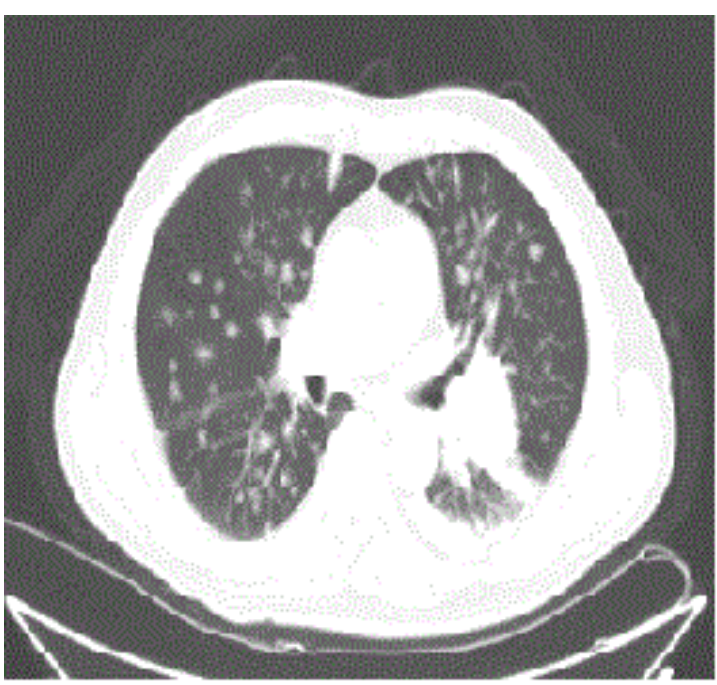

a

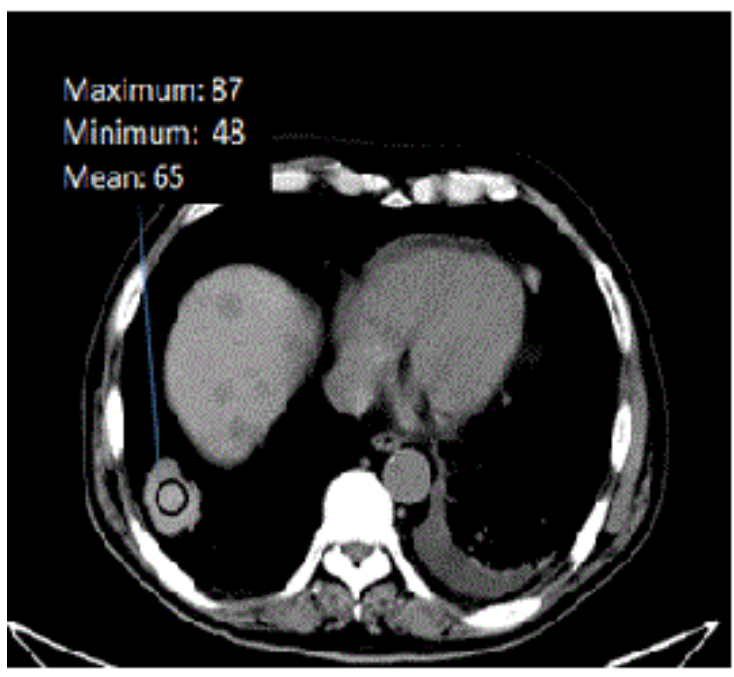

C

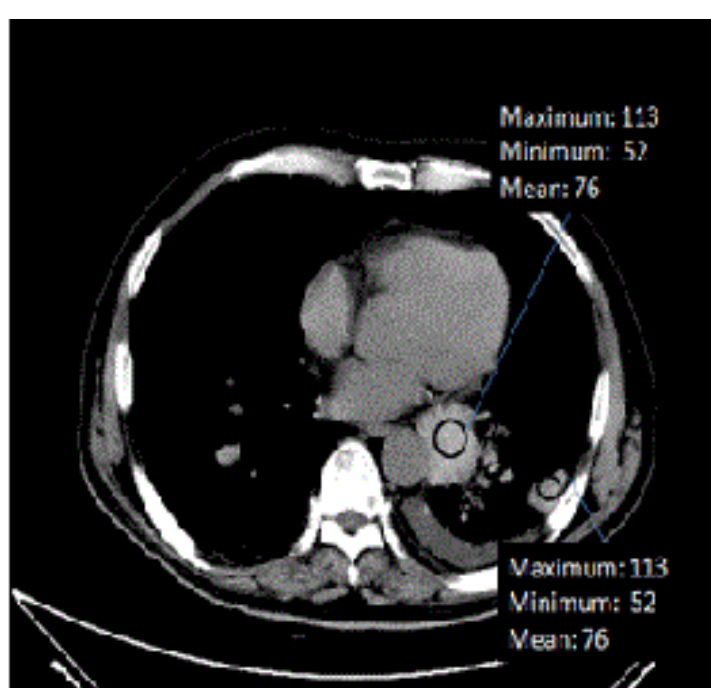

b

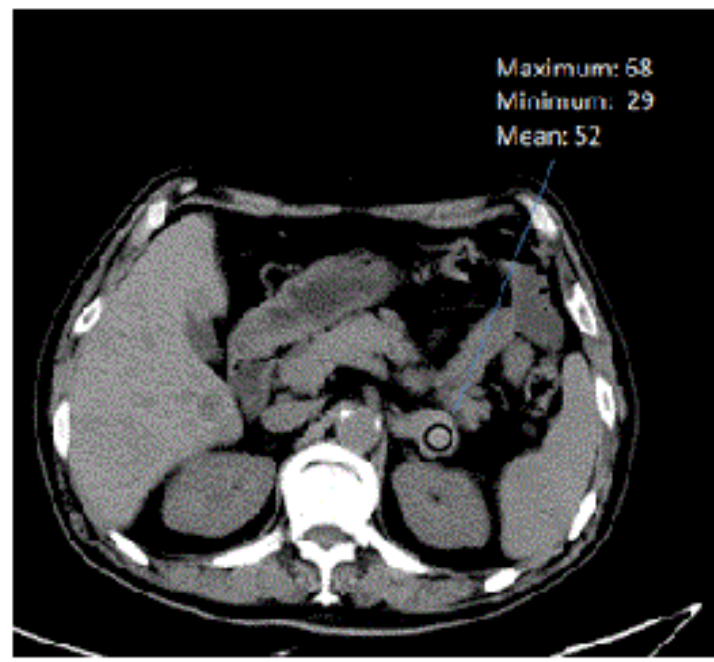

d

Figure 1: Computed tomography showing (a) multiple nodules and mass in bilateral lung lobe in lung window, (b) the homogenous mass in mediastinal window near hilum (mean CT value $76 \mathrm{HU}$ ) and near pleura (mean CT value of $76 \mathrm{HU}$ ), (c) right lower lung lobe mass (mean CT value of $65 \mathrm{HU}$ ), (d) left adrenal gland (mean CT value of $52 \mathrm{HU}$ ).

A percutaneous transthoracic needle biopsy was performed, and the histology showed melanoma cells with melanin pigments. Immunohistochemically (Figure 3), tumor cells were positive for human melanoma black 45(HMB-45), S-100 protein, Melan-A and VIMENTIN, while pancytokeratin (CK), CK5, CK6, thyroid transcription factor (TTF)-1, were negative. According to these pathologic findings, the tumor was diagnosed as malignant melanoma of the lung. Thorough dermatologic and other organ, including the eyes, gastrointestinal tract, and oral and nasal cavities examination, which can be primary sites of melanoma, didn't show evidence of melanoma. The patient was explained about the disease and its prognosis and chemotherapy was advised. He received 2 cycles of chemotherapy. Later he refused further treatment. He died after one month of initial diagnosis of the disease.

\section{Literature Review}

\section{General literature review}

A literature search on PubMed and Medline database was performed using the key words 'pulmonary melanoma' or 'lung melanoma' and 'malignant melanoma', and yielded a total of 42 articles. Case reports in English language were included, and articles without CT imaging details were excluded. A total of 25 articles with reference information (Table 1) on 28 patients were used for the literature review and this analysis. Of 28 patients, 17 were male and 11 were female; the median age was 62 years (range, 13-89 years). The past medical history of PMM cases showed no inherited tendency and included tuberculosis, hypertension, diabetes mellitus, other malignancies such as basal cell carcinoma, prostate carcinoma, and 
Citation: Byanju S, Chen J, Zhu DY, Liao MY (2018) Primary Pulmonary Malignant Melanoma: A Case Report and Literature Review. Med Rep

Case Stud 3: 155. doi:10.4172/2572-5130.1000155

Page 3 of 8

cervical carcinoma. 21 patients had no significant past medical history.

Smoking did not appear to be a risk factor, since only 6 of the 28 patients had a history of smoking.

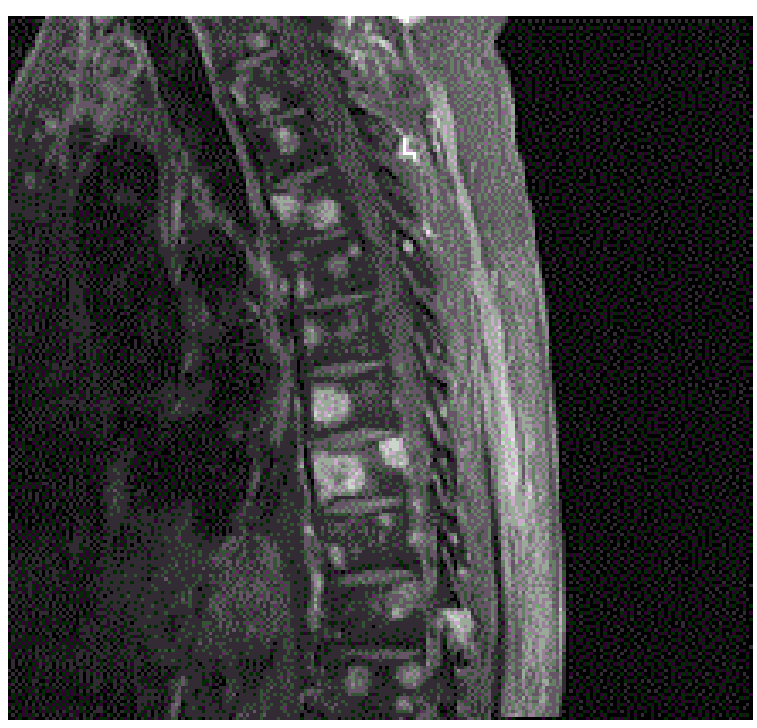

a

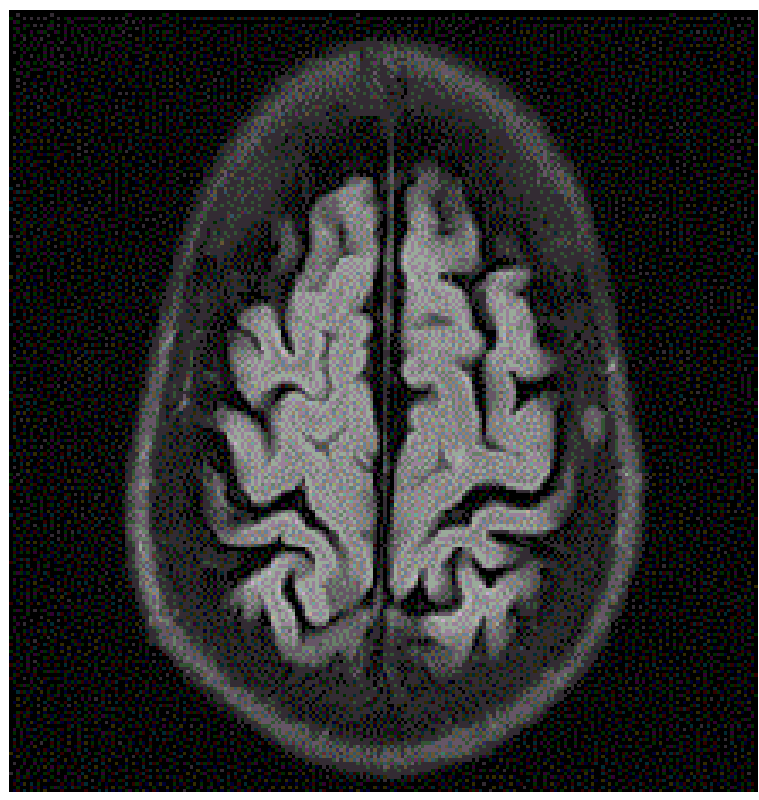

C

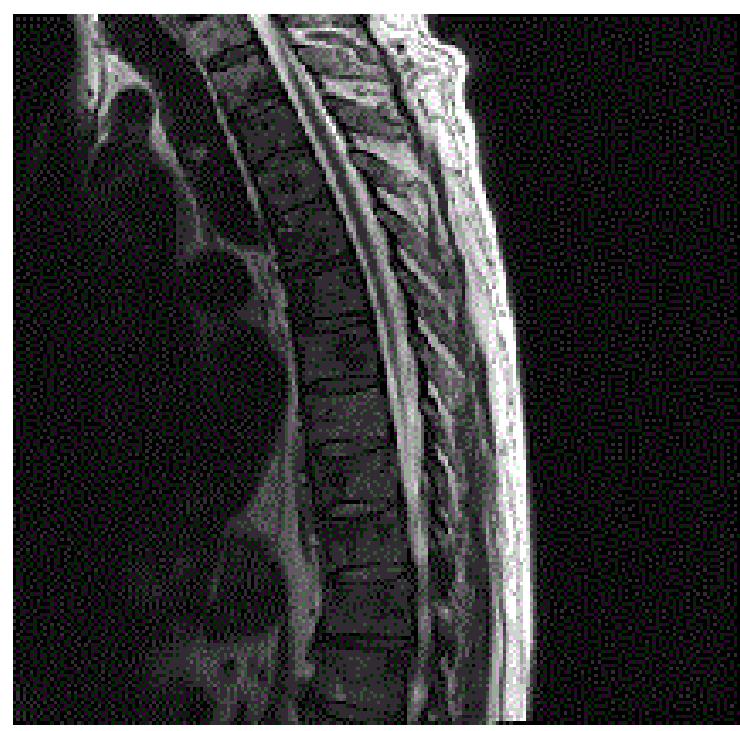

b

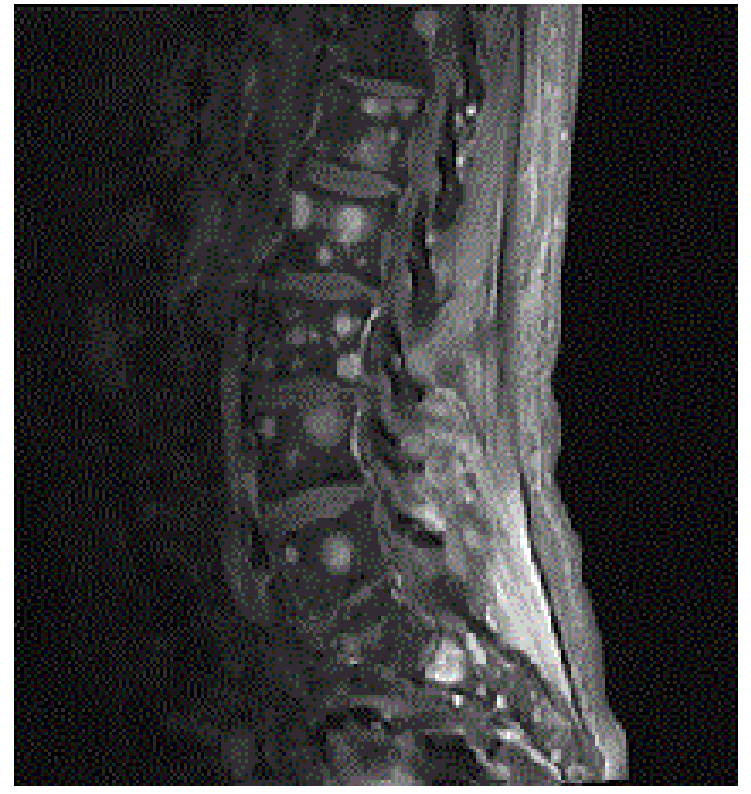

d

Figure 2: Magnetic resonance imaging showing metastatic lesion with (a) hyper-intensity on T1WI in thoracic vertebras, (b) hypo-intensity on T2WI in thoracic vertebra, (c) hyper-intensity on T1WI in skull, (d) hyper-intensity on T1WI in lumbar vertebras.

\section{Clinical presentation of PMM}

Clinical presentation (Table 1) of PMM lacked specificity with patients presenting with pulmonary and/or extrapulmonary symptoms. Ten of the cases were asymptomatic and were incidental findings in routine examination. The pulmonary symptom was a persistent cough ( 10 of the 28 patients), progressive dyspnea ( 8 of the 28 patients), chest pain ( 4 of the 28 patients), sputum production ( 3 of the 28 patients), and hemoptysis ( 2 of the 28 patients). The extrapulmonary symptoms included significant weight loss ( 5 of the 28 patients), fatigue ( 3 of the 28 patients), anorexia ( 3 of the 28 patients), back pain, headache, neck pain, shoulder pain, nausea and hemiparesis. However, these symptoms were not common and depended on the site of metastasis. 
Citation: Byanju S, Chen J, Zhu DY, Liao MY (2018) Primary Pulmonary Malignant Melanoma: A Case Report and Literature Review. Med Rep

Page 4 of 8

\section{Chest imaging}

In chest radiography, all patients had a mass or opacity, some had infiltrates, multiple nodules, atelectasis, pleural effusion. In chest computed tomography (Table 1), according to literatures, primary pulmonary melanoma was distributed in bilateral upper lobe and lower lobe lungs, predominantly in the left lower lobe; usually solitary
(19 out of 28 patients) solid nodules or masses, lobulated (17 out of 28 ), with homogenous density (20 out of 28 ). Some were accompanied by central necrosis, consolidation, ground glass opacity, crazy paving pattern, collapse of lung lobe, pleural thickening and pleural effusion, mediastinal lymphadenopathy. The imaging findings lacked specificity.
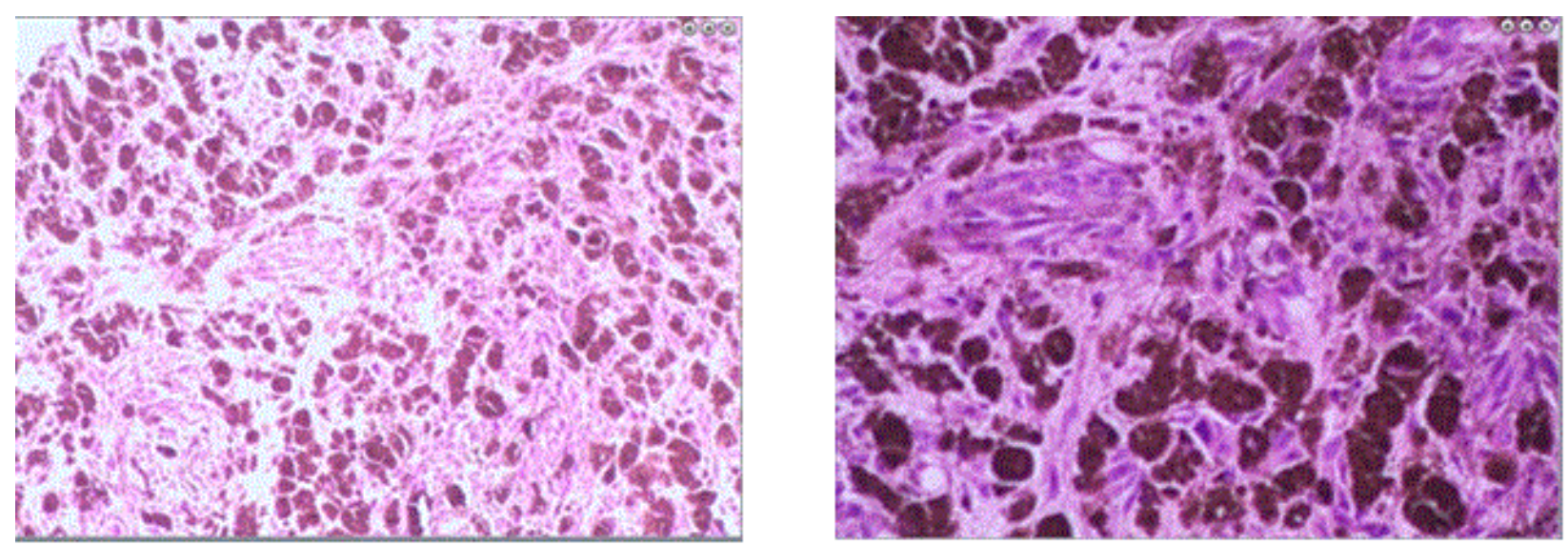

Figure 3: Immunohistochemistry of right lower pulmonary nodule showed that the tumor cells were CK (-), CK5/6 (-), HMB45 (+), Melan-A $(+)$, S-100 (+), TTF-1 (-), and VIMENTIN (+).

\begin{tabular}{|c|c|c|c|c|c|}
\hline $\begin{array}{l}\text { Author, year of } \\
\text { publication, } \\
\text { reference }\end{array}$ & $\begin{array}{l}\text { No. of } \\
\text { reported } \\
\text { patients }\end{array}$ & Clinical manifestations & $\begin{array}{l}\text { Primary imaging } \\
\text { features in } \mathrm{CT}\end{array}$ & Treatment & Outcome \\
\hline Alghanem et al. [6] & 1 & Asymptomatic & $\begin{array}{l}\text { A heterogeneous } \\
\text { lobulated } 6 \mathrm{~cm} \text { mass in } \\
\text { posterior segment of } \\
\text { LLL }\end{array}$ & Lobectomy & $\begin{array}{l}\text { Alive } 2.5 \text { years } \\
\text { postop }\end{array}$ \\
\hline Dountsis et al. [7] & 1 & Cough & $\begin{array}{l}\text { A well-defined mass in } \\
\text { RUL }\end{array}$ & Pneumonectomy+adjuvant therapy & $\begin{array}{l}\text { Alive } 18 \mathrm{mths} \\
\text { postop }\end{array}$ \\
\hline Ülger Al et al. [4] & 1 & $\begin{array}{lr}\text { Cough, } & \text { dyspnoea, } \\
\text { sputum } & \text { production, } \\
\text { weight loss } & \end{array}$ & $\begin{array}{lr}\text { Multiple heterogeneous } \\
\text { mass in RLL } \\
\text { pleural thickening and } \\
\text { subcarinal } & \text { LN } \\
\text { enlargement } & \end{array}$ & None & $\begin{array}{l}\text { Died } 1 \text { mth after } \\
\text { discharge }\end{array}$ \\
\hline Reddy et al. [8] & 1 & Weight loss & $\begin{array}{l}\text { A lobulated } \\
\text { homogenous } 3 \times 8 \mathrm{~cm} \\
\text { mass with high denstity } \\
\text { in LLL }\end{array}$ & Lobectomy & $\begin{array}{l}\text { Alive } 8 \mathrm{mths} \\
\text { postop }\end{array}$ \\
\hline Maeda at al. [9] & 1 & Asymptomatic & $\begin{array}{lr}\text { A homogeneous, } \\
\text { illdefined, lobulated } 4 \times \\
3 \mathrm{~cm} \text { masswith pleural } \\
\text { thickening } \\
\text { subcarinal } \\
\text { enlargement }\end{array}$ & Lobectomy & $\begin{array}{l}\text { Died } 6 \text { mths } \\
\text { postop }\end{array}$ \\
\hline Seitelman et al. [10] & 1 & Asymptomatic & $4.5 \mathrm{~cm}$ mass in LLL & Lobectomy & $\begin{array}{l}\text { Alive } 5 \quad \text { yrs } \\
\text { postop }\end{array}$ \\
\hline Lazarou et al. [11] & 1 & $\begin{array}{l}\text { Weakness, Upper GIT } \\
\text { symptoms }\end{array}$ & $\begin{array}{l}\text { A heterogeneous } \\
\text { lobulated } 5 \times 9 \mathrm{~cm} \\
\text { mass with high density } \\
\text { in RLL with mediastinal } \\
\text { LN enlargement }\end{array}$ & Pneumonectomy & $\begin{array}{l}\text { Died } 13 \mathrm{mths} \\
\text { after diagnosis }\end{array}$ \\
\hline
\end{tabular}


Citation: Byanju S, Chen J, Zhu DY, Liao MY (2018) Primary Pulmonary Malignant Melanoma: A Case Report and Literature Review. Med Rep Case Stud 3: 155. doi:10.4172/2572-5130.1000155

Page 5 of 8

\begin{tabular}{|c|c|c|c|c|c|}
\hline \multirow[b]{2}{*}{ Neri et al. [12] } & \multirow[b]{2}{*}{2} & Asymptomatic & $\begin{array}{l}\text { A round high density } \\
\text { homogenous } 2 \times 3 \mathrm{~cm} \\
\text { mass in LLL }\end{array}$ & Lobectomy+Adjuvant chemotherapy & $\begin{array}{l}\text { Died } 6 \mathrm{mths} \\
\text { postop }\end{array}$ \\
\hline & & Bloody sputum & $\begin{array}{l}\text { A round uniform high } \\
\text { density homogenous } 4 \\
\times 3 \mathrm{~cm} \text { mass in RUL } \\
\text { with mediastinal LN } \\
\text { enlargement }\end{array}$ & Lobectomy+Adjuvant chemotherapy & $\begin{array}{l}\text { Died } 6 \mathrm{mths} \\
\text { postop }\end{array}$ \\
\hline Zuckermann et al. [13] & 1 & Asymptomatic & $\begin{array}{l}\text { A well-defined } 5 \mathrm{~cm} \\
\text { mass in RUL }\end{array}$ & Lobectomy+Adjuvant chemotherapy & 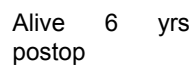 \\
\hline \multirow[b]{2}{*}{ Gong et al. [5] } & \multirow[b]{2}{*}{2} & Persistent cough & $\begin{array}{l}\text { Multiple ill-defined } \\
\text { mass in LUL, LLL }\end{array}$ & Chemotherapy & $\begin{array}{l}\text { Died } 4 \text { mths } \\
\text { after diagnosis }\end{array}$ \\
\hline & & Dyspnoea, weakness & $\begin{array}{l}\text { A round high density } \\
\text { homogenous } 6 \times 4 \mathrm{~cm} \\
\text { mass in RLL }\end{array}$ & Lobectomy+Adjuvant chemotherapy & $\begin{array}{l}\text { Alive } 1.5 \text { yrs } \\
\text { postop }\end{array}$ \\
\hline Ouarssani et al. [14] & 1 & $\begin{array}{l}\text { Cough, } \\
\text { production, } \\
\text { chest pain, hemoptym } \\
\text { weight loss }\end{array}$ & $\begin{array}{lr}\text { Well } & \text { defined } \\
\text { homogeneous } & \text { mildly } \\
\text { enhanced } 6 \mathrm{~cm} & \text { mass } \\
\text { in LLL and } 2 \mathrm{~cm} \text { mass } \\
\text { in RLL with } & \text { pleural } \\
\text { effusion } & \text { and } \\
\text { mediastinal } & \text { LN } \\
\text { enlargement } & \end{array}$ & Chemotherapy & $\begin{array}{l}\text { Died } 2 \text { mths } \\
\text { after diagnosis }\end{array}$ \\
\hline $\begin{array}{l}\text { Lares dos Santos et } \\
\text { al. [15] }\end{array}$ & 1 & Dyspnoea, chest pain & $\begin{array}{l}\text { An irregular } \\
\text { homogeneous } 3.5 \mathrm{~cm} \\
\text { mass in LUL with } \\
\text { collapse of LUL }\end{array}$ & Chemoradiotherapy & $\begin{array}{l}\text { Alive } 12 \mathrm{mths} \\
\text { after diagnosis }\end{array}$ \\
\hline $\begin{array}{l}\text { Kamaleshwaran et al. } \\
\text { [16] }\end{array}$ & 1 & Neck pain & $\begin{array}{l}\text { Multiple ill defined } \\
\text { homogeneous mass } 3 \\
\mathrm{~cm}, 2 \mathrm{ccm} \text { in LLL }\end{array}$ & Pneumonectomy+Chemoradiotherapy & $\begin{array}{l}\text { Alive } 1 \mathrm{yr} \text { after } \\
\text { diagnosis }\end{array}$ \\
\hline Gupta et al. [17] & 1 & $\begin{array}{l}\text { Chest pain, dry cough, } \\
\text { fever, anorexia, weight } \\
\text { loss }\end{array}$ & $\begin{array}{l}\text { A large } 8 \times 9 \mathrm{~cm} \\
\text { heterogeneously } \\
\text { enhancing mass in the } \\
\text { LUL with central non- } \\
\text { enhancing necrotic } \\
\text { areas and pleural } \\
\text { effusion }\end{array}$ & None & $\begin{array}{l}\text { Died } 2 \mathrm{mths} \\
\text { after diagnosis }\end{array}$ \\
\hline Filippini et al. [18] & 1 & $\begin{array}{l}\text { Persisient cough, fever, } \\
\text { dyspnoea }\end{array}$ & $\begin{array}{l}\text { Mixed ground-glass } \\
\text { and lobar consolidation } \\
\text { in RUL, and ground } \\
\text { glass with crazy paving } \\
\text { appearance in RLL with } \\
\text { multiple bilateral } \\
\text { nodules }\end{array}$ & Chemo-immunotherapy & $\begin{array}{l}\text { Died } 3 \mathrm{mths} \\
\text { after diagnosis }\end{array}$ \\
\hline Hwang et al. [19] & 1 & Asymptomatic & $\begin{array}{l}\text { A heterogeneous } \\
\text { enhancing } 8 \mathrm{~cm} \text { mass } \\
\text { with an inner low } \\
\text { attenuating portion in } \\
\text { RLL with pleural } \\
\text { effusion }\end{array}$ & None & $\begin{array}{l}\text { Died } 3 \mathrm{mths} \\
\text { after diagnosis }\end{array}$ \\
\hline Mahowald et al. [20] & 1 & Cough & $\begin{array}{l}\text { A homogenous } 7.5 \mathrm{~cm} \\
\text { mass in LUL with } \\
\text { pleural thickening }\end{array}$ & Pneumonectomy & $\begin{array}{l}\text { Alive } 60 \mathrm{mths} \\
\text { postop }\end{array}$ \\
\hline \multirow{2}{*}{$\begin{array}{l}\text { Postrzech-Adamczyk } \\
\text { et al. [21] }\end{array}$} & \multirow{2}{*}{2} & $\begin{array}{l}\text { Persistent cough, } \\
\text { exertional dyspnoea }\end{array}$ & $\begin{array}{l}\text { A heterogeneous solid } \\
\text { cystic } 6 \mathrm{~cm} \text { mass in } \\
\text { RUL with mediastinal } \\
\text { LN enlargement }\end{array}$ & Adjuvant chemotherapy & $\begin{array}{l}\text { Died } 6 \mathrm{mths} \\
\text { after diagnosis }\end{array}$ \\
\hline & & Right sided hemiparesis & $\begin{array}{l}\text { A homogenous high } \\
\text { density large round } 5 \\
\mathrm{~cm} \text { mass in LUL }\end{array}$ & Palliative treatment & $\begin{array}{l}\text { Died } 3 \mathrm{mths} \\
\text { after diagnosis }\end{array}$ \\
\hline
\end{tabular}




\begin{tabular}{|c|c|c|c|c|c|}
\hline & & & $\begin{array}{l}\text { surrounded with } \\
\text { ground-glass opacity. }\end{array}$ & & \\
\hline Zhang et al. [22] & 1 & Asymptomatic & 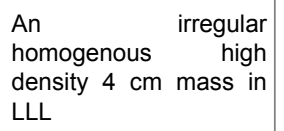 & Pneumonectomy+Adjuvant chemotherapy & $\begin{array}{l}\text { Alive } 18 \mathrm{mths} \\
\text { postop }\end{array}$ \\
\hline Agarwal et al. [23] & 1 & $\begin{array}{l}\text { Anorexia, weight loss, } \\
\text { progressive dyspnoea, } \\
\text { chest pain, back pain, } \\
\text { abdominal distention }\end{array}$ & $\begin{array}{l}\text { Circumferential } \\
\text { thickening of pleura on } \\
\text { left with its extension } \\
\text { as a heterogenous } \\
\text { lobulated mass, } \\
\text { collapse of left lung and } \\
\text { pleural effusion }\end{array}$ & None & $\begin{array}{l}\text { Died } 25 \text { days } \\
\text { after admission }\end{array}$ \\
\hline Baniak et al. [24] & 1 & $\begin{array}{l}\text { Weakness, chest pain, } \\
\text { nausea, back pain }\end{array}$ & $\begin{array}{lr}\text { pleural } & \text { based } \\
\text { heterogenous } & \text { nodular } \\
\text { mass in LLL } & \text { with } \\
\text { effusion } & \end{array}$ & Immunomodulators & $\begin{array}{l}\text { Died } 4 \text { mths } \\
\text { after diagnosis }\end{array}$ \\
\hline Feng et al. [25] & 1 & $\begin{array}{l}\text { Dry cough, hemoptysis, } \\
\text { dyspnoea }\end{array}$ & 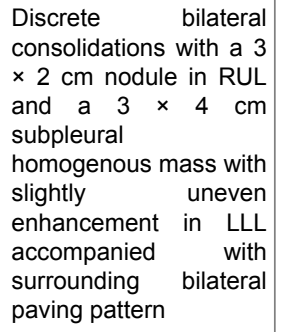 & None & $\begin{array}{l}\text { Died } 2 \text { mths } \\
\text { after diagnosis }\end{array}$ \\
\hline Kim et al. [26] & 1 & Productive cough & $\begin{array}{l}\text { A multi-lobulated } 5 \times \\
3.4 \mathrm{~cm} \text { mass } \\
\text { homogeneous } \\
\text { enhancement }(28 \mathrm{HU}) \\
\text { in } \mathrm{RUL}\end{array}$ & None & $\begin{array}{l}\text { Died } 3 \text { mths } \\
\text { after diagnosis }\end{array}$ \\
\hline $\begin{array}{l}\text { Kyriakopoulos et al. } \\
\text { [27] }\end{array}$ & 1 & $\begin{array}{l}\text { Headache, nausea, } \\
\text { ataxic gait }\end{array}$ & $\begin{array}{l}\text { A heterogeneous ill } \\
\text { defined mass in RUL } \\
\text { with hilar } \mathrm{LN} \\
\text { enlargement }\end{array}$ & Radiotherapy+biochemotherapy & $\begin{array}{l}\text { Died } 5 \text { mths } \\
\text { after diagnosis }\end{array}$ \\
\hline Yamamoto et al. [28] & 1 & Asymptomatic & $\begin{array}{l}\text { A homogenous well- } \\
\text { defined } 13 \mathrm{~mm} \text { nodule } \\
\text { in LLL }\end{array}$ & Lobectomy + chemo immunotherapy & $\begin{array}{l}\text { Died } 15 \mathrm{mths} \\
\text { post op }\end{array}$ \\
\hline Present case, 2017 & 1 & $\begin{array}{l}\text { Productive cough, back } \\
\text { pain }\end{array}$ & $\begin{array}{l}\text { A large irregular } \\
\text { heterogeneous } 6.9 \times \\
6.5 \mathrm{~cm} \text { mass in } \mathrm{LUL} \\
\text { and irregular solid } 4.3 \times \\
3.6 \mathrm{~cm} \text { mass in RLL } \\
\text { with pleural effusion }\end{array}$ & Chemotherapy & $\begin{array}{l}\text { Died } 1 \mathrm{mth} \text { after } \\
\text { diagnosis }\end{array}$ \\
\hline
\end{tabular}

Table 1: Cases of primary pulmonary malignant melanomas reported in the literature.

\section{Treatment and prognosis}

Lobectomy or pneumonectomy with lymph node dissection is the mainstay of treatment in patients diagnosed with primary pulmonary malignant melanoma. Adjuvant therapy has not been done in a randomized fashion due to the rarity of the disease. Surgical resection was the primary treatment (14 of the 28 reported patients) while adjuvant systemic treatment was delivered just to 9 patients (Table 1). In addition, palliative radiotherapy to distant sites had been administered in 3 patients (Table 1). In general, it seems that most patients (15 of the 28 patients) were diagnosed with metastatic disease.
The sites of metastatic involvement included the contralateral lung, liver, brain, bones, and pericardium. The prognosis (Table 1) was very poor and the majority (19 of 28 patients) survived less than 18 months.

\section{Discussion}

Melanoma is a malignant neoplasm of melanocytes which usually occurs on the skin but may occur in other primary sites, such as oral cavity, paranasal sinuses, larynx, esophagus, liver, vagina, cervix and anorectal regions [1]. When we encounter pulmonary masses, clinically diagnosis of primary pulmonary $\mathrm{MM}$ is rarely taken into 
consideration, as primary PMM is very rare. Additionally, there aren't specific radiologic features for pulmonary MM [26]. The gold standard for the diagnosis of pulmonary $\mathrm{MM}$ is the histological features. Approximately $5-10 \%$ of patients with metastatic melanoma have a primary melanoma of unknown origin [26]. Thus, meticulous systemic assessment of the whole body is to be done [2].

The diagnosis of primary PMM is based on clinical and pathological criteria [26]. The clinical criteria include the presence of a solitary lung mass or nodule, histopathology diagnosis confirmed by immunohistochemistry and/or electron microscopy, absence of history suggestive of a previous melanoma, and no demonstrable melanoma outside the thorax at the time of diagnosis [27]. So, our case also fulfils these criteria and can be diagnosed as primary PMM.

Radiologic features are ingenious to narrow down the differential diagnosis. But many studies have not stated the detailed imaging findings in their case reports. In CT scan, PMM presents as a well demarcated round or lobulated solitary nodule or mass with heterogeneous enhancement, and with or without mediastinal lymph nodes enlargements [25]. Our case revealed the nodules or masses had higher CT value (mean CT value of $67 \mathrm{HU}$ in mediastinum window) with mild enhancement in the chest CT. The metastatic nodules also had higher CT value. MM is composed melanocytes, rich with melanin granules, which would cause the higher CT value than other tumor [26]. But almost none of the literature has described it. This imaging finding may be a specific parameter to form a differential diagnosis of MM. Furthermore, MRI examination provides more detailed information in primary PMM. On MRI, melanotic and amelanotic patterns of malignant melanoma are seen. A melanotic pattern shows hyper-intensity on T1WI and hypo-intensity on T2WI, while an amelanotic pattern shows hypo-intensity or iso-intensity on T1WI and hyper-intensity or iso-intensity on T2WI $[29,30]$. So, MRI is the best diagnostic method for detecting brain metastases of MM [26]. Likewise, in our case, the MR images of the metastatic lesions were hyper-intense on T1WI and hypo-intense on T2WI. Recent reports suggest that FDG-PET/CT can efficiently detect micrometastatic lesions of MM, that could not be seen in CT scan and aid in restaging and management of recurred MM [26]. But, there is few information on this matter.

In histology, primary PMM resembles skin or mucosa and metastatic melanoma $[3,7,9]$. The tumor is composed of nesting of epithelioid cells, or spindle cells arranged in fascicles, with or without melanin granule deposition. The immunohistochemical markers are pathognomonic to distinguish a primary $\mathrm{MM}$ from a metastatic one. In melanoma, S-100, HMB-45, vimentin, (pan-CK, CK7, CK20, EMA), keratin, P63, TTF-1, CD45, are positive and muscular markers (actin and desmin) are negative [31]. S-100 and HMB-45 markers expression is decreased in metastatic melanomas [26,31]. In our patient, HMB-45, S-100, Melan-A and VIMENTIN were positive aiding to the confirmation of the diagnosis. Therefore, final diagnosis of a primary pulmonary $\mathrm{MM}$ of the lung is based upon combined clinical, radiological, histological findings and immunehistochemical staining analysis [5].

As for the treatment, patients diagnosed with primary pulmonary malignant melanoma should undergo lobectomy or pneumonectomy with lymph node dissection [1,9]. At the time of diagnosis of the primary tumor, most patients with mucosal melanoma will have metastases. However, adjuvant therapy has not been studied in a randomized fashion because of the rarity of the disease. The role of chemotherapy is not fully clarified. Bio-chemotherapy, combination of chemotherapy and immunotherapy, is an acceptable choice for aggressive bulky disease always after taking into consideration patients' performance status and comorbidities, and the relatively expanded toxicity profile of the combination therapy [27]. Palliative radiation therapy is utilized when bulky metastatic disease is present [27]. Due to the rarity of primary pulmonary malignant melanomas, randomized trials for assessing different treatment modalities are demanding.

\section{Conclusion}

In conclusion, we presented a case of pulmonary malignant melanoma with metastasis and had a poor prognosis, and summarized the key aspects of this rare disease based on the available published literatures. We suggest, when encountered with homogenous nodules or masses with higher CT value in lung and metastases, and on MRI hyper-intensity on T1WI and hypo-intensity on T2WI, with the exception of hemorrhage, PMM should be taken into consideration as a differential diagnosis.

\section{Acknowledgement}

Ethics approval and consent to participate: our hospital approves of publishing this case report and informed consent was taken from the patient's wife.

Competing interests: The authors declare that they have no competing interests.

\section{Funding: None}

Authors' contributions: LMY presented the idea of the case report. SB wrote the draft of manuscript. JC, DYZ analysed and interpreted the clinical details and images for the manuscript. SB, LMY was involved in its critical revision before submission. All authors read and approved the final manuscript.

\section{References}

1. Markovic SN, Erickson LA, Rao RD, Weeing RH, Pockaj BA, et al. (2007) Malignant Melanoma in the 21st Century, Part 1: Epidemiology, Risk Factors, Screening, Prevention, and Diagnosis. Mayo Clin Proc 82: 364-380.

2. Parkin DM, Bray F, Ferlay J, Pisani P (2005) Global Cancer Statistics, 2002. CA Cancer J Clin 55: 74-108.

3. Katz KA, Jonasch E, Hodi FS, Soiffer R, Kwitkiwski K, et al. (2005) Melanoma of unknown primary: experience at Massachusetts General Hospital and Dana-Farber Cancer Institute. Melanoma Res 15: 77-82.

4. Ülger AF, Şen E, Erekul S, Gönüllüa U (2005) Malignant Melanoma of Lung: Is It Easy to Determine Its Origin? Arch Bronconeumol 41: 102-104.

5. Gong L, Liu X-Y, Zhang W-D, Zhu S-J, Yao L, et al. (2012) Primary pulmonary malignant melanoma: a clinicopathologic study of two cases. Diagn Pathol 7: 123.

6. Alghanem AA, Mehan J, Hassan AA (1987) Primary Malignant Melanoma of the Lung. J Surg Oncol 34: 109-112.

7. Dountsis A, Zisis C, Karagianni E, Dahabreh J (2003) Primary Malignant Melanoma of the Lung: A Case Report. World J Surg Oncol 1: 26.

8. Reddy VS, Mykytenko J, Giltman LI, Mansour KA (2007) Primary Malignant Melanoma of the Lung: Review of Literature and Report of a Case. Am Surg 73: 287-289.

9. Maeda R, Isowa N, Onuma H, Miura H, Tokuyasu H, et al. (2009) Primary malignant melanoma of the lung with rapid progression. Gen Thorac Cardiovasc Surg 57: 671-674. 
10. Seitelman E, Donenfeld P, Kay K, Takabe K, Andaz S, et al. (2011) Successful treatment of primary pulmonary melanoma. J Thorac Dis 3: 207-208.

11. Lazarou I, Purek L, Duc C, Licker M-J, Spiliopoulos A, et al. (2011) Primary malignant achromic melanoma of the lung. Thorac Cancer 5 85-88.

12. Neri S, Komatsu T, Kitamura J, Otsuka K, Katakami N, et al. (2011) Malignant melanoma of the lung: Report of two cases. Ann Thorac Cardiovasc Surg 17: 170-173.

13. Zuckermann B, Papiashvilli M, Bar I (2011) Primary pulmonary malignant melanoma of right upper lobe of lung. Isr Med Assoc J 13: 440-441.

14. Ouarssani A, Atoini F, Reda R, Ait F, Lhou MIR (2012) Malignant melanoma of the lung: a case report. Pan Afr Med J 11: 68.

15. Lares dos Santos C, Fernandes LR, Meruje M, Barata F (2013) Primary pulmonary melanoma: the unexpected tumour. BMJ Case Rep.

16. Kamaleshwaran KK, Natarajan S, Parthiban J, Mehta S, Radhakrishnan K, et al. (2014) Rare case of extradural spinal metastasis from primary lung malignant melanoma detected with fluorine-18 fluorodeoxyglucosepositron emission tomography/computed tomography. Indian J Nucl Med 29: 57-58.

17. Gupta A, Bhattacharya D, Jain S, Suri JC (2015) Primary Malignant Melanoma of the Lung: Case Report and Literature Review. Indian J Chest Dis Allied Sci 57: 181-184.

18. Filippini A, Zorzi F, Bna' C, Arnaboldi A, Sabatini T (2015) Dark sputum: An atypical presentation of primary pulmonary malignant melanoma. Respir Med case reports 15: 118-120.

19. Hwang KB, Hwang KE, Jung JW, Oh SJ, Park MJ, et al. (2015) Primary pulmonary malignant melanoma: An unexpected tumor. Tuberc Respir Dis (Seoul) 78: 272-275

20. Mahowald MK, Aswad BI, Okereke IC, Ng T (2015) Long-term survival after pneumonectomy for primary pulmonary malignant melanoma. Ann Thorac Surg 99: 1428-1430.

21. Postrzech-Adamczyk K, Chabowski M, Głuszczyk-Ferenc B, Wodzinska A, Muszczynska-Bernhard B, et al. (2015) Malignant melanoma of the lung: Case series. Kardiochirurgia i Torakochirurgia Pol 12: 72-76.
22. Zhang X, Wang Y, Du J (2015) Primary malignant melanoma of left lower lobe of lung: A case report and review of the literature. Oncol Lett 10: 528-530.

23. Agarwal P, Nambiyar K, Kaushal M, Bhardwaj M (2016) Primary Malignant Melanoma of Pleura A Case Report and Literature Review. Diagn Cytopathol 44: 648-652.

24. Baniak N, Podberezin M, Kanthan SC, Kanthan R (2017) Primary pulmonary/pleural melanoma in a 13 year-old presenting as pleural effusion. Pathol Res Pract 213: 161-164.

25. Feng Y, Zhao J, Yang Q, Xiong W, Zhen G, et al. (2016) Pulmonary melanoma and "crazy paving" patterns in chest images: a case report and literature review. BMC Cancer 16: 592.

26. Kim SR, Yoon H-Y, Jin GY, Choe YH, Park SY, et al. (2016) Pulmonary malignant melanoma with distant metastasis assessed by positron emission tomography-computed tomography. Thorac Cancer 7: 503-507.

27. Kyriakopoulos C, Zarkavelis G, Andrianopoulou A, Papoudou-Bai A, Stefanou D, et al. (2017) Case Report Primary Pulmonary Malignant Melanoma冈: Report of an Important Entity and Literature Review. Case Rep Oncol Med 2017: 8654326.

28. Yamamoto Y, Kodama K, Maniwa T, Takeda M, Tanaka Y, et al. (201) Primary malignant melanoma of the lung囚: A case report. Mol Clin Oncol 7: 39-41.

29. Woodruff WW, Djang WT, McLendon RE, Heinz ER, Voorhees DR (1987) Intracerebral malignant melanoma: High-field-strength MR imaging. Radiology 165: 209-213.

30. Escott EJ (2001) A Variety of Appearances of Malignant Melanoma in the Head: A Review. Radiographics 21: 625-639.

31. Plaza JA, Suster D, Perez-Montiel D (2007) Expression of Immunohistochemical Markers in Primary and Metastatic Malignant Melanoma: A Comparative Study in 70 Patients Using a Tissue Microarray Technique. Appl Immunohistochem Mol Morphol 15: 421-425. 